\title{
PENGARUH MODEL PEMBELAJARAN TEAM ASSISTED INDIVIDUALIZATION BERBASIS TRI HITA KARANA TERHADAP KOMPETENSI PENGETAHUAN PKn
}

\author{
${ }^{1}$ Desak Gede Mahardani Santhi, ${ }^{2}$ Ni Ketut Suarni, ${ }^{3}$ Komang Sujendra Diputra \\ 1,3Jurusan Pendidikan Dasar, Universitas Pendidikan Ganesha, Singaraja, Indonesia \\ ${ }^{2}$ Jurusan IImu Pendidikan, Psikologi dan Bimbingan, Universitas Pendidikan \\ Ganesha, Singaraja, Indonesia \\ e-mail: santhimahardani@yahoo.co.id, niketut.suarni, \\ komangsujendra.diputra@undiksha.ac.id
}

\begin{abstract}
Abstrak
Penelitian ini bertujuan untuk mengetahui pengaruh model pembelajaran Team Assisted Individualization (TAl) berbasis Tri Hita Karana terhadap kompetensi pengetahuan PKn siswa kelas V SDN 1 Ubung, Kecamatan Denpasar Utara. Jenis penelitian ini yaitu eksperimen semu dengan rancangan nonequivalent post-test only control group design. Populasi penelitian ini adalah seluruh siswa kelas V di SDN 1 Ubung yang berjumlah 112 siswa. Pengambilan sampel menggunakan teknik simple random sampling. Sampel penelitian ini yaitu siswa kelas $\mathrm{V}$ B yang berjumlah 37 siswa sebagai kelompok eksperimen dan siswa kelas V C yang berjumlah sama yaitu 37 siswa sebagai kelompok kontrol. Data dikumpulkan menggunakan kompetensi pengetahuan PKn siswa dengan metode tes. Instrumen yang digunakan yaitu tes kompetensi pengetahuan PKn berupa tes objektif. Data dianalisis dengan menggunakan analisis statistik deskriptif dan analisis statistik inferensial yaitu uji-t dengan rumus separated varians. Hasil menunjukkan nilai thitung $(8,60)>$ ttabel $(1,666)$. Berdasarkan hasil penelitian tersebut, dapat disimpulkan bahwa model pembelajaran team assisted individualization (TAI) berbasis tri hita karana berpengaruh terhadap kompetensi pengetahuan PKn siswa kelas V SDN 1 Ubung, Kecamatan Denpasar Utara.
\end{abstract}

Kata kunci: team assisted individualization, tri hita karana, kompetensi pengetahuan PKn.

Abstract
This study aims to determine the effect of Tri Hita Karana based Team Assisted Individualization (TAI) learning model on PKn knowledge competency in fifth grade students of Ubung 1 Elementary School, North Denpasar District Academic Year 2018/2019. This type of research is a quasi-experimental nonequivalent post-test only control group design. The population of this study were all fifth grade students at Ubung 1 Elementary School, totaling 112 students. Sampling uses simple random sampling technique. The sample of this study were students of class $\mathrm{V} B$, which amounted to 37 students as the experimental group and students of class V C with the same number, 37 students as the control group. Data were collected using PKn knowledge competencies of students with test methods. The instrument used was the Civics knowledge competency test in the form of objective tests. Data were analyzed using descriptive statistical analysis and inferential statistical analysis, namely $t$-test with separated variance formula. The results show a value of tcount $(8.60)>t$ table $(1,666)$. Based on the results of these studies, it can be concluded that the tri hita karana based assisted individualization (TAl) learning model has an effect on PKn knowledge competency in fifth grade students of Ubung 1 Elementary School, North Denpasar District Academic Year 2018/2019.

Keywords: team assisted individualization, tri hita karana, PKn knowledge competence 


\section{PENDAHULUAN}

Pesatnya perkembangan ilmu pengetahuan dan teknologi yang dipengaruhi adanya era globalisasi menuntut kesadaran manusia untuk dapat beradaptasi dan meningkatkan kualitasnya. Pendidikan memegang peranan penting dalam meningkatkan kualitas sumber daya manusia. Karena pendidikan merupakan pondasi utama dalam mengelola, mencetak, dan meningkatkan sumber daya manusia yang handal dan berwawasan sehingga mampu untuk menjawab tantangan dimasa mendatang.

Mewujudkan proses belajar mengajar sesuai UU No. 20 Tahun 2003, sangat diperlukan dengan meningkatkan inovasi kemampuan guru dalam kegiatan proses belajar mengajar. Hal ini sangat perlu diperhatikan dalam dunia pendidikan terutama sekolah dasar guna meningkatkan kualitas diri siswa dalam bermasyarakat, berbangsa, dan bernegara. Karena pada jenjang ini siswa memperoleh kemampuan dasar untuk mengembangkan potensi, keterampilan, dan nantinya dapat melanjutkan pendidikan ke jenjang berikutnya. Guru sebagai pendidik mempunyai pengaruh cukup besar terhadap tercapainya tujuan sesuai dengan tuntutan pendidikan saat ini.

Langkah awal untuk membangun bangsa yang cerdas dan membentuk warga negara yang baik dapat dilakukan dengan meningkatkan mutu pendidikan. Dalam meningkatkan mutu pendidikan salah satu cara yang dilakukan pemerintah adalah mengembangkan dan menyempurnakan kurikulum dengan mengubahnya menjadi kurikulum 2013.

Pembelajaran pada Kurikulum 2013 adalah pembelajaran tematik terpadu. Pembelajaran tematik terpadu merupakan pembelajaran yang menggabungkan beberapa materi pelajaran ke dalam sebuah tema salah satunya yaitu PKn. Susanto (2013:224) menyatakan bahwa "PKn merupakan mata pelajaran yang digunakan sebagai wahana untuk mengembangkan dan melestarikan nilai luhur dan moral yang berakar pada budaya bangsa Indonesia". PKn wajib diberikan di sekolah baik dari tingkat dasar sampai tinggi karena tujuan PKn adalah memberikan pemahaman dan pembiasaan dalam kehidupan sehari-hari yang ditunjang oleh pengetahuan dan membentuk karakteristik siswa yang nantinya bisa menjadi warga negara yang cerdas dan baik dalam menghadapi permasalahan dalam lingkungan kehidupan bermasyarakat, berbangsa dan bernegara. Hal ini didukung oleh pendapat Sumardjoko (2013:111) yang menyatakan bahwa "warga negara yang dimaksud adalah warga negara yang menguasai pengetahuan (knowledge), keterampilan (skills), sikap dan nilai (attitudes and values) yang dapat dimanfaatkan untuk menumbuhkan rasa kebangsaan dan cinta tanah air". Pentingnya PKn di sekolah dasar adalah sebagai upaya pemberian pemahaman dan kesadaran jiwa setiap peserta didik untuk menumbuhkan rasa kesetiaan dan kecintaan terhadap bangsa dan negaranya sebagai generasi penerus yang tahu akan hak dan kewajiban untuk menjadi warga negara Indonesia yang cerdas, terampil dan berkarakter yang diamanatkan oleh Pancasila dan UUD 1945 (Susanto, 2013).

Mewujudkan peserta didik yang diharapkan, maka sangat penting bagi guru untuk meningkatkan perubahan kemampuan inovasi dalam proses pembelajaran yang dapat menciptakan pembelajaran yang bermakna dan menyenangkan (Ananda, 2018). Pada materi pembelajaran PKn mengandung konsep nilai yang umumnya bersifat abstrak. Oleh karena itu, dalam memberikan materi pelajaran PKn, guru tidak hanya mentransfer pengetahuan yang diberikan kepada peserta didik dalam mengingat saja, karena sebagian siswa yang memiliki kemampuan akademik yang berbeda belum tentu dapat memahami sepenuhnya apa yang diajarkan oleh guru tersebut.

Pada kenyataannya masih banyak terjadi masalah dalam memberikan pembelajaran PKn di SD. Penurunan pembentukan karaker peserta didik dipengaruhi oleh dilema politik 
pada masa lalu yang menyebabkan mata pelajaran PKn cenderung kurang menarik, dianggap sepele, membosankan, dan munculnya kesan negatif serta kecenderungan guru yang menerapkan pembelajaran konvensional kepada siswa (Setiawan, 2014:63). Wartini (2014) menemukan masalah dalam pembelajaran PKn, yaitu kurang optimalnya sikap sosial dan hasil belajar PKn yang terjadi pada siswa kelas VI Sekolah Dasar Jembatan Budaya yang disebabkan oleh kurangnya penggunaan model pembelajaran inovatif, sehingga pembelajaran PKn kurang bermakna bagi siswa. Banyak yang beranggapan bahwa PKn merupakan mata pelajaran yang sulit karena berisi konsep-konsep untuk dihafalkan sehingga membuat siswa lebih tertarik terhadap mata pelajaran lainnya (Rachmawati, dkk 2014).

Berdasarkan observasi dan hasil wawancara yang dilakukan pada hari Rabu tanggal 14 November 2018 pada siswa kelas V di SD Negeri 1 Ubung, Kecamatan Denpasar Utara diketahui kompetensi pengetahuan siswa pada muatan materi PKn yang diperoleh sebagian besar masih belum tercapai secara optimal. Hal ini dibuktikan dari hasil nilai UAS siswa dalam pembelajaran PKn, yang sebagian besar belum mampu mencapai KKM (Kriteria Minimal) yang ditetapkan pada SD tersebut. Seperti yang dipaparkan pada tabel 1. sebagai berikut.

Tabel 1

Rata-Rata Nilai UAS PKn Kelas V di SD Negeri 1 Ubung

\begin{tabular}{cccc}
\hline No & Kelas & KKM & Nilai rata-rata \\
\hline 1 & V A & 75 & 66,7 \\
\hline 2 & V B & 75 & 65,02 \\
\hline 3 & V C & 75 & 62,37 \\
\hline & & (Sumber: Wali Kelas V SD Negeri 1 Ubung)
\end{tabular}

(Sumber: Wali Kelas V SD Negeri 1 Ubung)

Berdasarkan tabel 1, dipandang perlu ada peningkatan kompetensi pengetahuan PKn siswa. Temuan ini juga diperkuat oleh hasil wawancara yang dilakukan pada tanggal yang sama yaitu 14 November 2018 bersama guru kelas V SD di SD Negeri 1 Ubung, Kecamatan Denpasar Utara yang menyatakan bahwa rendahnya nilai UAS PKn siswa disebabkan oleh beberapa faktor, antara lain (1) Kurangnya penerapan model-model pembelajaran yang inovatif, menyebabkan siswa cepat jenuh dalam mengikuti proses pembelajaran yang diberikan, (2) Kurangnya waktu yang dibutuhkan karena jumlah siswa yang cukup banyak sehingga tujuan pembelajaran belum tercapai secara maksimal, (3) Dalam proses pembelajaran, guru kurang menumbuhkan rasa tanggung jawab dan kerja sama yang baik dalam kelompok yang telah ditentukan untuk menyelesaikan tugas yang diberikan, (4) Siswa kurang aktif untuk menanyakan hal-hal yang belum dipahami selama mengikuti pembelajaran.

Mengatasi permasalahan tersebut, tentunya perlu perbaikan dan inovasi dalam proses pembelajaran. Hal tersebut didukung oleh pendapat Dewi (2016) yang menyatakan bahwa "salah satu jenis model pembelajaran yang tepat diterapkan guru dalam mengajarkan PKn yaitu kooperatif learning". Model pembelajaran adalah pedoman yang dapat membantu meningkatkan aktifitas kegiatan pembelajaran siswa dengan jelas yang dapat mempengaruhi kognitif, afektif dan psikomotor siswa (Marliani, 2015). Jenis kooperatif learning yang sangat cocok untuk diterapkan pada pembelajaran PKn yaitu menggunakan model pembelajaran Team Assisted Individualization (TAI). Model pembelajaran Team Assisted Individualization ini salah satu alternatif yang dapat memecahkan masalah hasil belajar PKn siswa (Hijiyah, 2013). Model pembelajaran Team Assisted Individualization ini memiliki keunggulan, yaitu pembelajaran kooperatif dikombinasikan dengan pembelajaran 
individual yang dapat meningkatkan keterlibatan siswa secara aktif dalam kelompok melalui perannya sebagai tutor sebaya sehingga setiap anggota kelompok memiliki rasa tanggung jawab dan pembelajaran menjadi efektif (Ratri \& Joko, 2013). Shoimin (2014:200) menyatakan bahwa "model pembelajaran Team Assisted Individualization memiliki dasar pemikiran yaitu untuk mengadaptasikan pembelajaran terhadap perbedaan individual berkaitan dengan kemampuan maupun pencapaian prestasi siswa". Hal ini didukung oleh pendapat Arrahim \& Serly (2018) yang menyatakan bahwa "Team Assisted Individualization (TAI) merupakan model pembelajaran yang membentuk kelompok kecil yang heterogen dengan latar belakang cara berpikir yang berbeda untuk saling membantu terhadap siswa lain yang membutuhkan bantuan". Beberapa penelitian di atas dapat disintesiskan bahwa model pembelajaran Team Assited Individualization (TAI) adalah pembelajaran kooperatif yang dikombinasikan dengan pembelajaran individual sehingga siswa berperan sebagai tutor sebaya untuk meningkatkan kemampuan akademik dan keaktifan belajar siswa.

Model pembelajaran Team Assisted Individualization (TAI) termasuk metode cooperatif learning yang dikombinasikan dengan pembelajaran individual, dimana setiap perbedaan individual dilihat dari kemampuan akademik dibentuk menjadi kelompok kecil untuk meningkatkan motivasi dan ketercapaian belajar siswa. Siswa yang memiliki akademik bagus akan membantu siswa yang memiliki kemampuan akademik rendah, sehingga seluruh anggota kelompok dituntut untuk menguasai tugas yang diberikan guru demi keberhasilan kelompoknya. Ini akan menimbulkan keterlibatan seluruh siswa secara aktif untuk meningkatkan kompetensi pengetahuan siswa. Ada beberapa kelebihan dan kelemahan yang dimiliki dalam menerapkan model pembelajaran Team Assited Individualization (TAI). Hal ini dapat dilihat dari kelebihan yang dimiliki, kelebihan dalam pembelajaran kooperatif ini adalah adanya hubungan interaksi antara siswa satu dengan siswa lainnya dengan menerima perbedaan yang dimiliki masing-masing anggota kelompok untuk saling kerja sama (Slavin, 2008). Pernyataan tersebut didukung oleh pendapat Widyasari (2017:3) menyatakan bahwa "kelebihan model pembelajaran TAl yaitu melibatkan siswa untuk aktif dalam proses belajar, siswa diajarkan bagaimana bekerjasama dalam suatu kelompok dan adanya tanggung jawab dalam kelompok dalam menyelesaikan permasalahannya". Siswa akan menyadari bahwa dengan saling membantu akan tercipta hubungan yang baik antar sesama dan belajar menjadi lebih mudah.

Terciptanya hubungan interaksi yang baik dalam proses pembelajaran dapat didasari dengan adanya konsep Hindu di Bali yang dapat dijadikan pedoman dalam menjaga hubungan yang baik yaitu Tri Hita Karana. Wiana (2007:5) menyatakan bahwa "mencapai kehidupan yang bahagia dengan melakukan hubungan harmonis dengan Tuhan (Parhyangan), dengan sesama manusia (Pawongan) dan dengan alam lingkungan sekitar (Palemahan) ini merupakan bagian Tri Hita Karana". Hal ini berkaitan pada proses pembelajaran dengan menjaga hubungan baik terhadap sesama manusia dapat diwujudkan melalui saling membantu dalam belajar, menjaga hubungan baik dengan Tuhan dapat diwujudkan melalui berdoa sebelum atau sesudah pembelajaran berlangsung dan menjaga hubungan baik dengan alam lingkungan sekitar dapat diwujudkan melalui menjaga kebersihan sesudah atau sebelum pembelajaran dimulai. Apabila seluruh siswa dapat menerapkan ajaran Tri Hita Karana, maka tercipta suasana pembelajaran nyaman dan bahagia. Jadi, penggunaan model pembelajaran Team Assisted Individualization (TAI) berbasis Tri Hita Karana bukan hanya meningkatkan pemahaman pembelajaran PKn siswa melalui interaksi yang terjadi di dalam kelompok, namun juga ada rasa nyaman belajar dalam menjalin hubungan yang baik dengan Tuhan dan lingkungan belajarnya. Hal ini dapat disintesiskan bahwa model pembelajaran Team Assisted Individualization (TAl) berbasis Tri 
Hita Karana adalah kombinasi antara pembelajaran kooperatif dengan pembelajaran individual yang berlandaskan Tri Hita Karana sehingga terjadi suatu hubungan yang harmonis dalam proses pembelajaran baik itu dengan Tuhan, sesama manusia, dan lingkungan.

Konsep Tri Hita Karana mengajarkan kepada umat manusia cara menjaga hubungan yang baik agar tetap harmonis dan hidup bahagia. Menjaga hubungan baik dapat dilakukan di lingkungan rumah, sekolah maupun masyarakat. Tri Hita Karana sebuah pedoman hidup bagi umat manusia untuk menjaga hubungan yang baik dengan Tuhan, sesama manusia dan alam lingkungan agar tercapai kehidupan yang harmonis. Hal tersebut didukung oleh pendapat Ani (2017) menyatakan bahwa "perlu untuk mengenalkan konsep Tri Hita Karana kepada peserta didik selaku penerus bangsa". Model pembelajaran Team Assisted Individualization (TAI) berbasis Tri Hita Karana dapat meningkatkan keberhasilan belajar siswa karena siswa berperan sebagai tutor sebaya dalam kegiatan pembelajarannya sehingga menciptakan hubungan yang baik dengan Tuhan, sesama manusia dan lingkungan.

Kompetensi adalah perpaduan antara pengetahuan, sikap dan keterampilan untuk mengukur keaktifan belajar peserta didik yang mengandung aspek ranah kognitif, sikap, dan keterampilan dalam proses pembelajaran. Maka dari itu, program yang telah direncanakan perlu mengetahui pencapaian kompetensi peserta didik yang diharapkan agar tercapainya tujuan pembelajaran (Kosasih, 2014). Kunandar (2015:165) menyatakan bahwa "penilaian kompetensi pengetahuan atau kognitif adalah penilaian yang dilakukan guru untuk mengukur tingkat pencapaian atau penguasaan peserta didik dalam aspek pengetahuan yang meliputi ingatan atau hafalan, pemahaman, penerapan atau aplikasi, analisis, sintesis, dan evaluasi". Kompetensi pengetahuan PKn adalah mengetahui sejauh mana kemampuan penguasaan dan pemahaman siswa dalam pengetahuan yang mencakup kemampuan mengingat, memahami, menerapkan, menganalisis, mensintesis, dan mengevaluasi pengetahuan belajar siswa yang berkaitan dengan materi PKn. Kompetensi pengetahuan dalam penelitian ini yang akan ditingkatkan adalah ranah kognitif karena ranah kognitiflah yang banyak dinilai oleh guru untuk mengetahui penguasaan pengetahuan siswa dalam materi yang dipelajari.

PKn adalah mata pelajaran yang dapat mengembangkan pembentukan karakter siswa dengan nilai luhur budaya bangsa Indonesia agar menjadi warga negara yang cerdas, baik, tahu hak dan kewajiban di lingkungan bermasyarakat, berbangsa, dan bernegara (Susanto, 2013). Materi pelajaran PKn ini mengandung muatan nilai yang bersifat abstrak sehingga materi PKn tidak bisa dihafal saja melalui pengetahuan. Tujuan PKn ialah mengembangkan manusia seutuhnya sesuai dengan nilai luhur bangsa Indonesia agar menjadi warga negara baik dan bertanggung jawab dalam menghadapi tantangan hidup di kehidupan sehari-hari (Maftuh, 2008). PKn sangat wajib dipelajari terutama dari tingkat dasar, hal ini tertuang dalam UU Nomor 20 Tahun 2003 tentang Sistem Pendidikan Nasional pada Pasal 37. Pentingnya pembelajaran PKn di Sekolah Dasar diajarkan untuk memberikan pemahaman dan pembiasaan diri peserta didik dalam proses pembelajaran melalui pengetahuan yang berhubungan dengan kehidupan sehari-hari sesuai dengan nilai luhur bangsa Indonesia agar memiliki bekal dalam kehidupan bermasyarakat, berbangsa, dan bernegara.

Penelitian ini didukung oleh penelitian sebelumnya yang telah dilakukan oleh Putra (2014) yang menyatakan bahwa model pembelajaran kooperatif tipe TAI (Team Assisted Individually) berbantuan media Power Point berpengaruh terhadap hasil belajar PKn siswa kelas V SD Gugus I Kecamatan Petang Badung. Selain itu, penelitian lain juga Dewi (2016) 
yang menyatakan bahwa model pembelajaran Team Assisted Individualization (TAI ) berbantuan media kartu bergambar berpengaruh terhadap hasil belajar PKn siswa kelas IV Gugus VI Kecamatan Buleleng Kabupaten Buleleng.

Berdasarkan pernyataan di atas, maka dilakukan penelitian tentang "Pengaruh Model Pembelajaran Team Assisted Individualization (TAI) Berbasis Tri Hita Karana Terhadap Kompetensi Pengetahuan PKn Siswa Kelas V SD Negeri 1 Ubung, Kecamatan Denpasar Utara".

\section{METODE}

Penelitian ini dilaksanakan di SD Negeri 1 Ubung, Kecamatan Denpasar Utara. Sedangkan waktu penelitian dilaksanakan pada rentang waktu semester II (dua). Jenis penelitian ini adalah penelitian eksperimen semu (Quasi Experimental Design) dengan rancangan Nonequivalent Post-test Only Control Group Design. Desain penelitian ini dapat dilihat pada tabel 2 berikut.

Tabel 2

Desain Penelitian

\begin{tabular}{ccc}
\hline Kelompok & Perlakuan & Post-test \\
\hline $\mathrm{E}$ & $\mathrm{X}$ & $\mathrm{O}_{1}$ \\
\hline $\mathrm{K}$ & - & $\mathrm{O}_{2}$ \\
\hline
\end{tabular}

(dimodifikasi dari Sugiyono, 2017)

Populasi pada penelitian ini adalah seluruh siswa kelas V SD Negeri 1 Ubung, Kecamatan Denpasar Utara. Banyaknya seluruh siswa adalah 112 siswa. Teknik penelitian ini adalah simple random sampling yang dilakukan melalui sistem undian. Sebelum melakukan pengundian, dilakukan uji kesetaraan dalam populasi yaitu analisis varian satu jalur untuk menentukan pemilihan kelas eksperimen dan kelas kontrol. Kelas eksperimen mendapat perlakuan khusus dengan menggunakan model pembelajaran Team Assisted Individualization berbasis Tri Hita Karana, sedangkan kelas kontrol tidak dibelajarkan dengan model pembelajaran Team Assisted Individualization berbasis Tri Hita Karana.

Cara melakukan sistem undian tersebut yaitu pengambilan sampel dilakukan dengan menulis tiga kelas yang ada pada kelas V SD Negeri 1 Ubung, Kecamatan Denpasar Utara dalam kertas kecil. Kemudian kertas kecil tersebut digulung dan dikocok. Selanjutnya, mengambil dua gulungan secara acak untuk dijadikan sampel penelitian. Dari hasil random yang dilakukan tersebut yang terpilih adalah kelas V B dan V C. Selanjutnya, pengundian kembali dilakukan untuk menentukan kelas eksperimen dan kelas kontrol dengan cara yang sama yaitu menulis kedua kelas pada kertas kecil. Kemudian digulung dan dipilih secara acak sehingga hasilnya adalah kelas V B yang berjumlah 37 siswa sebagai kelas eksperimen dan kelas V C yang berjumlah 37 siswa sebagai kelas kontrol. Jadi, seluruh sampel dalam penelitian ini adalah 74 siswa.

Metode yang digunakan untuk mengumpulkan data adalah metode tes, dengan menggunakan tes obyektif. Tes obyektif digunakan pada saat post-test. Data yang telah dikumpulkan dianalisis dengan menggunakan statistik deskriptif dan statistik inferensial. Statistik deskriptif merupakan statistik yang digunakan untuk menganalisis data dengan cara mendeskripsikan atau menggambarkan data yang telah terkumpul tanpa bermaksud membuat kesimpulan yang berlaku untuk umum. Statistik deskriptif yang digunakan dalam penelitian ini yaitu mean (rata-rata), median, modus, standar deviasi, dan varians. 
Sedangkan statistik inferensial adalah teknik statistik yang digunakan untuk menganalisis data sampel dan membuat kesimpulan berdasarkan keputusan diterima atau ditolaknya hipotesis yang hasilnya diberlakukan untuk populasi. Statistik inferensial ini digunakan untuk menguji hipotesis melalui uji anava satu jalur yang diawali dengan analisis prasyarat yaitu uji normalitas sebaran data dan uji homogenitas. Setelah melakukan analisis prasyarat, kemudian dilakukan uji hipotesis menggunakan uji-t untuk mengetahui pengaruh yang signifikan kompetensi pengetahuan PKn antara kelompok siswa yang dibelajarkan dengan model pembelajaran team assisted individualization (TAI) berbasis tri hita karana dan kelompok siswa yang tidak dibelajarkan dengan model pembelajaran team assisted individualization (TAl) berbasis tri hita karana pada siswa kelas V SD Negeri 1 Ubung, Kecamatan Denpasar Utara.

\section{HASIL DAN PEMBAHASAN}

Data kelompok eksperimen adalah data hasil kompetensi pengetahuan PKn siswa kelas $\mathrm{V}$ yang mengikuti model pembelajaran Team Assisted Individualization (TAI) Berbasis Tri Hita Karana. Data kelompok kontrol adalah data hasil kompetensi pengetahuan PKn siswa kelas $\mathrm{V}$ yang tidak dibelajarkan dengan model pembelajaran Team Assisted Individualization (TAI) Berbasis Tri Hita Karana. Setelah melaksanakan penelitian, maka diperoleh data kompetensi pengetahuan PKn siswa berdasarkan hasil pemberian posttest yang dilaksanakan di kelas $\mathrm{V}$ B dan V C. Dari paparan data kompetensi pengetahuan PKn kelas $\mathrm{V}$ pada kelompok eksperimen terdapat 37 orang siswa dengan nilai tertinggi adalah 93 dan nilai terendah adalah 53. Sedangkan pada kelas kontrol terdapat 37 orang siswa dengan nilai tertinggi adalah 83 dan nilai terendah adalah 27.

Berdasarkan perhitungan hasil posttest, kelompok eksperimen yang dibelajarkan melalui model pembelajaran Team Assisted Individualization (TAI) Berbasis Tri Hita Karana memperoleh mean $=76,32$, median $=76,23$ Modus $=77,7$, standar deviasi $=11,39$, dan varians $=129,73$. Hasil perhitungan disajikan dalam bentuk histogram pada Gambar 1 berikut.

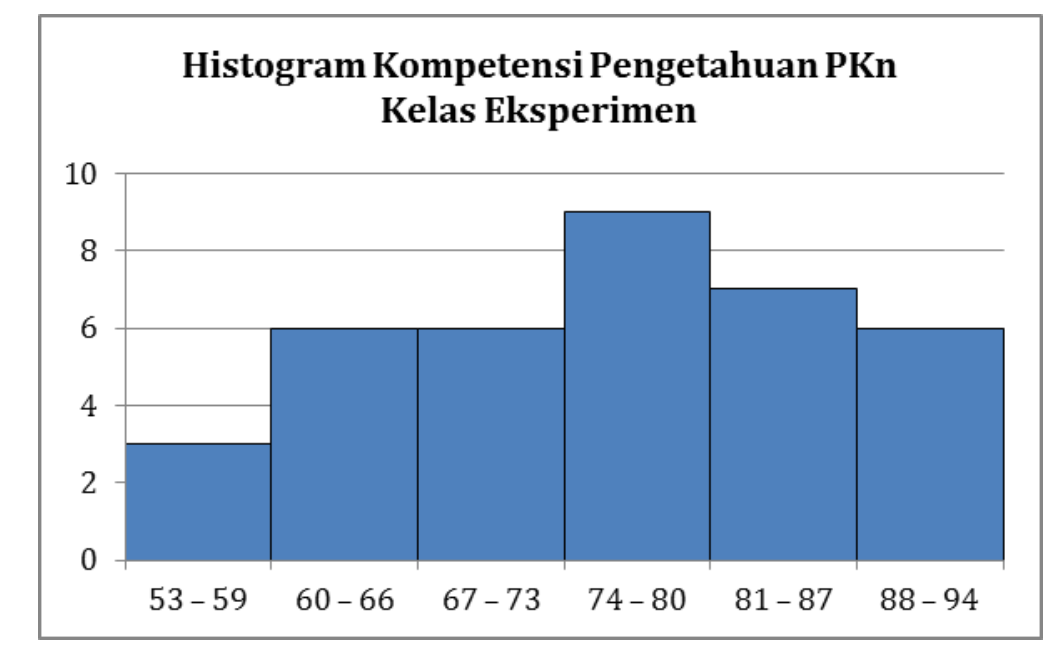

Gambar 1. Histogram Data Kompetensi Pengetahuan PKn Kelompok Eksperimen

Sedangkan pada kelompok kontrol yang tidak dibelajarkan dengan model pembelajaran Team Assisted Individualization (TAI) Berbasis Tri Hita Karana memperoleh mean 50,86, median $=58,7$, modus $=64,6$, standar deviasi $=13,97$, dan varians $=195,16$. Hasil perhitungan disajikan dalam bentuk histogram pada Gambar 2 berikut. 


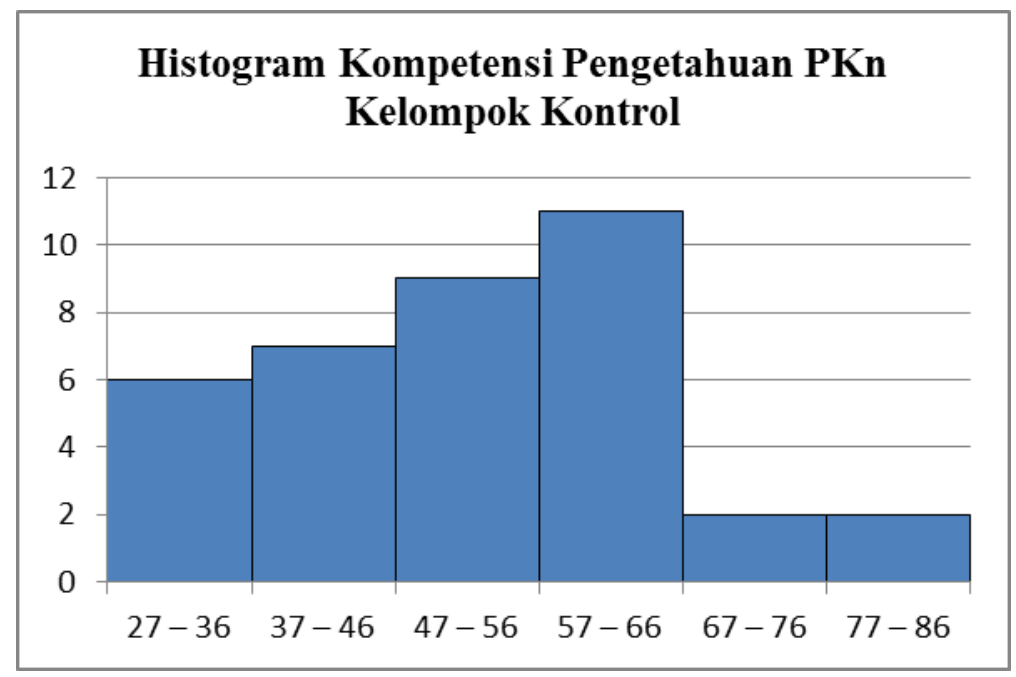

Gambar 2. Histogram Data Kompetensi Pengetahuan PKn Kelompok Kontrol

Berdasarkan hasil uji normalitas sebaran data diuji dengan menggunaka rumus ChiSquare $\left(\chi^{2}\right)$ dengan kriteria pengujian data berdistribusi normal jika $\chi^{2}$ hitung $<\chi_{\text {tabel, }}^{2}$ dengan taraf signifikansi $5 \%$ dan derajat kebebasannya $\mathrm{dk}=(\mathrm{k}-2-1)$. Hasil uji normalitas memiliki kriteria $\mathrm{H}_{0}$ tolak jika $t_{\text {nitung }}>\mathrm{t}_{\text {tabel }}$ dan $\mathrm{H}_{1}$ terima jika $t_{\text {hitung }}<\mathrm{t}_{\text {tabel. }}$. Rangkuman hasil perhitungan uji-t antara kelompok eksperimen dan kelompok kontrol disajikan pada tabel 3 di berikut ini.

Tabel 3. Hasil Uji Normalitas Sebaran Data

\begin{tabular}{|c|c|c|c|c|}
\hline No. & $\begin{array}{c}\text { Kelompok Data } \\
\text { Kompetensi Pengetahuan } \\
\text { PKn }\end{array}$ & $x^{2}$ hitung & $\begin{array}{c}\text { Nilai Kritis dengan } \\
\text { Taraf Signifikansi } 5 \%\end{array}$ & Status \\
\hline 1 & Eksperimen & 3,489 & 7,815 & Normal \\
\hline 2 & Kontrol & 4,469 & 7,815 & Normal \\
\hline
\end{tabular}

Berdasarkan Tabel 3, hasil perhitungan menunjukkan bahwa diperoleh $\chi^{2}$ hitung posttest kelompok eksperimen adalah 3,489 dan tabel dengan taraf signifikansi $5 \%$ dan dk

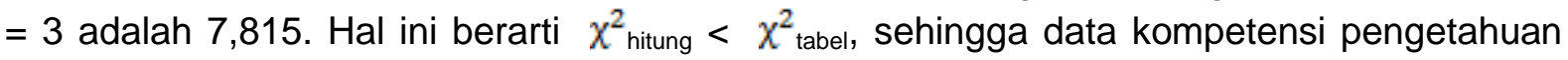
PKn siswa kelompok eksperimen berdistribusi normal. Sedangkan hasil perhitungan posttest kelompok kontrol adalah 4,469 dan tabel dengan taraf signifikansi $5 \%$ dan $\mathrm{dk}=3$ adalah 7,815 . Hal ini berarti $\chi^{2}$ hitung $<\chi_{\text {tabel }}^{2}$, sehingga data kompetensi pengetahuan PKn siswa kelompok kontrol berdistribusi normal.

Uji homogenitas varians dilakukan terhadap varians pasangan antar kelompok eksperimen dan kontrol. Uji yang digunakan adalah uji-F dengan kriteria jika $F_{\text {hitung }}<F_{\text {tabel }}$ maka sampel homogen. Hasil uji tersebut dapat disajikan pada tabel 4 berikut.

Tabel 4. Hasil Uji Homogenitas Varians Antar Kelompok

\begin{tabular}{lccc}
\hline \multicolumn{1}{c}{ Sumber Data } & Fhitung & $\begin{array}{c}\text { Ftabel dengan Taraf } \\
\text { Signifikansi 5\% }\end{array}$ & Status \\
\hline $\begin{array}{l}\text { Posttest Kelompok } \\
\text { Eksperimen dan Kontrol }\end{array}$ & 1,50 & 1,69 & Homogen \\
\hline
\end{tabular}

Berdasarkan Tabel 4, diketahui bahwa hasil posttest kelompok eksperimen dan kelompok kontrol dengan $\mathrm{db}$ pembilang $=37-1=36$ dan $\mathrm{db}$ penyebut $=37-1=36$ pada taraf signifikansi $5 \%$ diketahui Ftabel $=1,69$ dan Fhitung $=1,50$ sehingga $F_{\text {hitung }}<F_{\text {tabel }}(1,50<$ 1,69). Hal ini berarti varians kedua kelompok bersifat homogen. 
Setelah data yang diperoleh telah memenuhi semua uji prasyarat, uji hipotesis dilakukan dengan menggunakan analisis uji-t sampel independent (tidak berkorelasi) dengan rumus separated varians kriteria pengujian adalah apabila $t_{\text {hitung }}$ lebih besar daripada $t_{\text {tabel }}\left(t_{\text {hitung }}>t_{\text {tabel }}\right)$, maka $\mathrm{H} 0$ ditolak dan $\mathrm{H} 1$ diterima dengan taraf signifikansi $5 \%$ dengan $\mathrm{db}=$ n1+n2 - 2. Hasil uji hipotesis disajikan pada tabel 5 berikut.

Tabel 5. Hasil Uji Hipotesis

\begin{tabular}{|c|c|c|c|c|c|c|}
\hline Kelompok & $\mathbf{N}$ & Mean & Varians $\left(\mathrm{s}^{2}\right)$ & $\overline{\text { Db }}$ & $t_{\text {hitung }}$ & $\mathbf{t}_{\text {tabel }}$ \\
\hline Eksperimen & 37 & 76,32 & 129,73 & \multirow[b]{2}{*}{72} & \multirow[b]{2}{*}{8,60} & \multirow[b]{2}{*}{1,666} \\
\hline Kontrol & 37 & 50,86 & 195,16 & & & \\
\hline
\end{tabular}

Berdasarkan hasil uji hipotesis pada Tabel 5 , diperoleh bahwa nilai $t_{\text {hitung }}=8,60$ dan $t_{\text {tabel }}=1,666$ untuk $d b=72(37+37-2)$ pada taraf signifikansi $5 \%$ sehingga nilai $t_{\text {hitung }}>t_{\text {tabel }}$ $(8,60>1,666)$, maka $\mathrm{H} 0$ ditolak dan $\mathrm{H} 1$ diterima. Jadi, terdapat pengaruh yang signifikan kompetensi pengetahuan PKn antara kelompok siswa yang dibelajarkan dengan model pembelajaran team assisted individualization (TAl) berbasis tri hita karana dan kelompok siswa yang tidak dibelajarkan dengan model pembelajaran team assisted individualization (TAI) berbasis tri hita karana pada siswa kelas V SD Negeri 1 Ubung, Kecamatan Denpasar Utara.

Perbedaan kompetensi pengetahuan PKn antara kelompok eksperimen dan kelompok kontrol dikarenakan dalam setiap tahapan pembelajaran dengan menggunakan model pembelajaran team assisted individualization melibatkan siswa dalam proses pembelajaran yang dapat meningkatkan keberhasilan belajar siswa, menumbuhkan tanggung jawab dalam menyelesaikan tugas yang diberikan, dapat saling membantu siswa yang mengalami masalah belajar secara berkelompok dan adanya dorongan dari anggota kelompok yang dapat membantu siswa untuk maju. Ketika menggunakan model pembelajaran team assisted individualization dengan tidak dibelajarkan menggunakan model pembelajaran team assisted individualization dalam proses pembelajaran memiliki pengaruh yang besar dan perbedaan dalam kompetensi pengetahuan PKn. Hal tersebut disebabkan karena langkah-langkah model pembelajaran team assisted individualization yang digunakan memberikan kesempatan kepada siswa untuk membentuk kelompok secara heterogen dilihat dari kemampuan akademik sebelumnya. Hal ini dapat dilihat dari kelebihan yang dimiliki, kelebihan dalam pembelajaran kooperatif ini adalah adanya hubungan interaksi antara siswa satu dengan siswa lainnya dengan menerima perbedaan yang dimiliki masing-masing anggota kelompok untuk saling kerja sama (Slavin, 2008).

Kedua, model pembelajaran team assisted individualization ini siswa lebih diajarkan dengan adanya tanggung jawab antar kelompok yang akan ditentukan dari keberhasilan kelompok, pada kegiatan akhir pembelajaran siswa akan diberikan skor dan penghargaan berupa bintang emas, perak dan perunggu apabila siswa dapat mengerjakan tugas dengan baik melalui kerja sama antar kelompok. Hal ini dapat memberikan dorongan dari anggota kelompoknya kepada siswa yang mengalami kesulitan belajar untuk meningkatkan kemajuan belajar siswa. Temuan ini sejalan dengan Widyasari (2017:3) menyatakan bahwa "kelebihan model pembelajaran TAI yaitu melibatkan siswa untuk aktif dalam proses belajar, siswa diajarkan bagaimana bekerjasama dalam suatu kelompok dan adanya tanggung jawab dalam kelompok dalam menyelesaikan permasalahannya".

Ketiga, guru hanya berperan sebagai fasilitator dan motivator sehingga siswa diajarkan bagaimana cara bekerjasama yang baik dengan anggota kelompok melalui peran siswa sebagai tutor sebaya, dengan adanya tutor sebaya ini dapat membantu siswa yang merasa malu bertanya kepada gurunya dapat bertanya langsung dengan teman anggota kelompoknya. Jadi, timbul keaktifan belajar siswa melalui bertukar pikiran antar siswa yang 
mengalami kesulitan belajar dengan siswa yang memiliki kemampuan akademik tinggi. Temuan ini sejalan dengan Dewi (2016:3) menyatakan bahwa "model pembelajaran ini mengasah siswa untuk dapat bekerjasama dan bertukar pikiran dengan temannya sehingga siswa yang sebelumnya kurang mengerti menjadi lebih mengerti mengenai materi yang diajarkan". Apabila siswa mampu menjawab tugas yang diberikan oleh gurunya, maka siswa nanti akan diberi sebuah kuis yang dijawab siswa secara mandiri untuk mengetahui apakah siswa tersebut telah mampu menguasai pembelajaran tersebut dengan baik.

Berdasarkan temuan-temuan pada kelompok eksperimen, dapat diketahui bahwa model pembelajaran team assisted individualization memiliki keunggulan sehingga tepat digunakan dalam pembelajaran. Kelebihan dari model pembelajaran team assisted individualization adalah 1) dibentuk kelompok dengan akademik yang berbeda untuk belajar menghargai adanya perbedaan dan mengurangi persaingan ,2) siswa berperan sebagai tutor sebaya dalam kelompok sehingga siswa yang mengalami kesulitan belajar dapat terbantu oleh siswa yang memiliki kemampuan akademik tinggi, 3) siswa diajarkan bagaimana bekerjasama dalam suatu kelompok, 4) siswa ikut terlibat dalam proses pembelajaran melalui diskusi kelompok, 5) menumbuhkan rasa motivasi dan tanggung jawab dalam menyelesaikan tugas yang diberikan.

Beberapa kelebihan ini yang mengakibatkan kompetensi pengetahuan PKn siswa yang dibelajarkan dengan model pembelajaran team assisted individualization lebih unggul dibandingkan dengan yang tidak dibelajarkan dengan model pembelajaran team assisted individualization. Apalagi dalam penerapannya model team assisted individualization ini dengan berbasis tri hita karana yang dapat meningkatkan keberhasilan belajar siswa karena siswa berperan sebagi tutor sebaya dalam kegiatan pembelajarannya sehingga menciptakan hubungan yang baik dengan Tuhan, sesama manusia dan lingkungan. Hal ini dapat memberi pengaruh dalam diri siswa saat melakukan doa sebelum pembelajaran dimulai maupun sesudah pembelajaran selesai (Parhyangan) untuk membiasakan diri siswa berdoa terlebih dahulu sebelum atau sesudah melakukan kegiatan, mengecek kebersihan kelas sebelum atau sesudah pembelajaran (Palemahan) sehingga siswa menjadi terbiasa untuk menjaga kebersihan kelas. Dengan adanya kegiatan Parhyangan dan Palemahan tersebut dapat menimbulkan interaksi antar siswa dalam kegiatan pembelajaran. Hal ini dapat dilihat dari keterlibatan siswa sebagai tutor sebaya dalam bekerja sama antar kelompok yang menimbulkan adanya interaksi dalam suatu proses pembelajaran (Pawongan) sehingga siswa berperan aktif dan membangun pengetahuannya sendiri. Jadi, dengan adanya Tri Hita Karana ini akan memberikan dampak dalam menumbuhkan karakteristik siswa yang nantinya akan berkaitan dengan kehidupan sehari-hari. Apabila siswa dapat diperkenalkan adanya konsep tri hita karana dapat membangun dan menanamkan karakteristik siswa untuk ke depannya (Ani, 2017). Oleh karena itu, dapat dipahami bahwa penggunaan model pembelajaran team assisted individualization berbasis tri hita karana berpengaruh terhadap kompetensi pengetahuan PKn.

Temuan-temuan tersebut dapat membuktikkan adanya pengaruh yang berbeda dari penggunaan model pembelajaran team assisted individualization berbasis tri hita karana dan tidak dibelajarkan dengan model pembelajaran team assisted individualization berbasis tri hita karana dalam pembelajaran. Hasil penelitian ini sesuai dengan hasil penelitian yang didapatkan oleh Hijriyah (2013) yang menyebutkan bahwa model pembelajaran Team Assisted Individualization ini salah satu alternatif yang dapat memecahkan masalah hasil belajar PKn siswa. Berdasarkan penelitian tersebut, penggunaan model pembelajaran team assisted individualization dalam pembelajaran telah menunjukkan hasil yang positif. Berdasarkan temuan-temuan yang ada pada penelitian ini, dapat dinyatakan bahwa model pembelajaran team assisted individualization (TAI) berbasis tri hita karana berpengaruh 
terhadap kompetensi pengetahuan PKn siswa kelas V SD Negeri 1 Ubung, Kecamatan Denpasar Utara.

\section{SIMPULAN}

Berdasarkan hasil pengujian hipotesis dan pembahasan hasil penelitian, maka simpulan dari penelitian ini adalah terdapat pengaruh yang signifikansi kompetensi pengetahuan PKn antara kelompok siswa yang dibelajarkan dengan model pembelajaran team assisted individualization (TAI) berbasis tri hita karana dan kelompok siswa yang tidak dibelajarkan dengan model pembelajaran team assisted individualization (TAI) berbasis tri hita karana pada siswa kelas V SD Negeri 1 Ubung, Kecamatan Denpasar Utara. Hal tersebut diperoleh dari hasil perhitungan uji-t menunjukkan bahwa nilai thitung yaitu 8,60 > ttabel yaitu 1,666 (dengan $\mathrm{db}=72$ dan taraf signifikansi $5 \%$ ), sehingga $\mathrm{H} 0$ ditolak dan $\mathrm{H} 1$ diterima. Dengan demikian, model pembelajaran team assisted individualization (TAI) berbasis tri hita karana berpengaruh terhadap kompetensi pengetahuan $\mathrm{PKn}$ siswa kelas $\mathrm{V}$ SD Negeri 1 Ubung, Kecamatan Denpasar Utara.

Saran dalam penelitian ini ditujukan kepada seluruh siswa agar selalu terlibat secara aktif dalam proses pembelajaran sehingga dapat mengasah kemampuan dan pemahaman belajarnya melalui peran siswa sebagai tutor sebaya dalam kelompok, kepada guru yang menemukan permasalahan yang sama dengan permasalahan penelitian ini khususnya dalam pembelajaran PKn agar merancang pembelajaran dengan menggunakan model pembelajaran team assisted individualization, sehingga pembelajaran menjadi lebih bermakna dan efektif, kepada kepala sekolah hendaknya mampu memberikan pembinaan kepada para guru untuk memilih dan menerapkan model pembelajaran yang tepat sesuai dengan materi pembelajaran dan karakteristik siswa agar dapat meningkatkan keaktifan dan hasil belajar siswa, kepada peneliti lain dapat menggunakan hasil penelitian ini sebagai acuan kepustakaan untuk melakukan penelitian dalam variabel yang sama atau variabel yang berbeda.

\section{Daftar Pustaka}

Ani, N. K. K. 2017. Pengaruh Model Pembelajaran Time Token Berbasis Tri Hita Karana Terhadap Hasil Belajar IPS Siswa Kelas V. e-journal Mimbar PGSD Undiksha, Volume 5, Nomor 2 (halaman 1-10).

Ananda, R. 2018. Peningkatan Pembelajaran PKn Dengan Penerapan Metode Role-Playing Siswa Kelas II SDN 003 Bangkinang Kota. Jurnal Basicedu, Volume 2, Nomor 1 (halaman 34-42).

Arrahim \& Serly Amalia. 2018. Penerapan Model Pembelajaran Kooperatif Tipe Team Assisted Individualization (TAl) Untuk Meningkatkan Kemampuan Pemecahan Masalah Pada Mata Pelajaran Matematika Kelas IV SD Negeri Wanasari 14 Cibitung, Bekasi. Jurnal Pedagogik, Volume 6, Nomor 1 (halaman 21-30).

Dewi, N. P. C. P. 2016. Pengaruh Model Pembelajaran Team Assisted Individualization Berbantuan Media Kartu Bergambar Terhadap Hasil Belajar PKn. e-journal Mimbar PGSD Undiksha, Volume 4, Nomor 1 (halaman 1-10).

Hijriyah, N. U. 2013. Keefektifan Model Pembelajaran Team Assisted Individualization Terhadap Hasil Belajar PKn. Jurnal of Elementary Education, Volume 2, Nomor 2 (halaman 35-41).

Kosasih. 2014. Strategi Belajar dan Pembelajaran Implementasi Kurikulum 2013. Bandung: Yrama Widya. 
Kunandar. 2015. Penilaian Autentik (Penilaian Hasil Belajar Peserta Didik Berdasarkan Kurikulum 2013) Suatu Pendekatan Praktis Disertai dengan Contoh. Jakarta: Rajawali Pers.

Maftuh, B. 2008. Internalisasi Nilai-Nilai Pancasila dan Nasionalisme Melalui Pendidikan Kewarganegaraan. Educationist, Volume 2, Nomor 2 (halaman 134-144).

Marliani, N. 2015. Peningkatan Kemampuan Berpikir Kreatif Matematis Siswa Melalui Model Pembelajaran Missouri Mathematics Project (MMP). Jurnal Formatif, Volume 5, Nomor 1 (halaman 14-25).

Putra, P. W. E. 2014. Pengaruh Model Pembelajaran Kooperatif Tipe TAI (Team Assited Individually) Berbantuan Media Powerpoint Terhadap Hasil Belajar PKn Siswa Kelas V SD Gugus I Kecamatan Petang Badung. e-journal Mimbar PGSD Undiksha, Volume 2, Nomor 1.

Rachmawati, S, Imam M, \& Umar H.M.S. 2014. Peningkatan Aktivitas dan Hasil Belajar Siswa Kelas VI Mata Pelajaran PKn Materi Pokok Demokrasi Melalui Penerapan Model Pembelajaran Scramble di SD Negeri Kademangan 1 Bondowoso. Jurnal Edukasi UNEJ, Volume 1, Nomor 1 (halaman 10-14).

Ratri, C. M. \& Joko. 2013. Perbedaan Model Pembelajaran Kooperatif Tipe Team Assisted Individualization (TAI) dan Model Pembelajaran Langsung Terhadap Hasil Belajar Siswa Pada Standar Kompetensi Merawat Peralatan Rumah Tangga Listrik Di SMK Negeri 2 Surabaya. Jurnal Pendidikan Teknik Elektro, Volume 2, Nomor 3 (halaman 913-920).

Setiawan, D. 2014. Pendidikan Kewarganegaraan Berbasis Karakter Melalui Penerapan Pendekatan Pembelajaran Aktif, Kreatif, Efektif dan Menyenangkan. Jurnal Pendidikan IImu-IImu Sosial, Volume 6, Nomor 2 (halaman 61-72).

Shoimin, A. 2014. 68 Model Pembelajaran Inovatif dalam Kurikulum 2013. Yogyakarta: ArRuzz Media.

Slavin, R. E. 2008. Cooperative Learning Teori, Riset dan Praktik. Bandung: Nusa Media.

Sugiyono. 2017. Metode Penelitian Kuantitatif, Kualitatif, dan R\&D. Bandung: Alfabeta.

Sumardjoko, B. 2013. Revitalisasi Nilai-Nilai Pancasila Melalui Pembelajaran PKn Berbasis Kearifan Lokal Untuk Penguatan Karakter dan Jati Diri Bangsa. Varia Pendidikan, Volume 25, Nomor 2 (halaman 110-123).

Susanto, A. 2013. Teori Belajar dan Pembelajaran di Sekolah Dasar. Jakarta: Kencana Prenadamedia Group.

Undang-Undang Republik Indonesia No.20 Tahun 2003 tentang Sistem Pendidikan Nasional. 2003. Jakarta: Depdiknas.

Wartini, I. A. K. M. 2014. Pengaruh Implementasi Pendekatan Saintifik Terhadap Sikap Sosial Dan Hasil Belajar PKn Di Kelas VI SD Jembatan Budaya, Kuta. e-journal Program Pascasarjana Undiksha, Volume 4.

Wiana. 2007. Tri Hita Karana Menurut Konsep Hindu. Surabaya: Paramita.

Widyasari, Ni Nym. 2017. Pengaruh Model Pembelajaran TAI Berbantuan Media Konkret Terhadap Hasil Belajar Matematika Siswa Kelas V. e-journal Mimbar PGSD Undiksha, Volume 5, Nomor 2 (Halaman 1-10). 